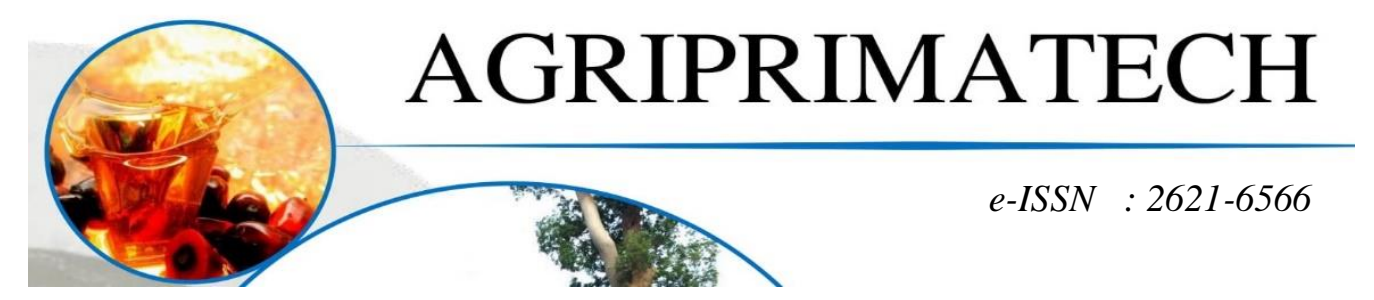

\title{
ANALISIS TATANIAGA KELAPA SAWIT (Elaeis guineensis Jacq.) (STUDI KASUS : KECAMATAN KUALUHSELATAN KABUPATEN LABUHAN BATU UTARA)
}

\author{
MARULI TUA SIRAIT ${ }^{1}$ \\ ${ }^{1}$ Fakultas Agroteknologi, Universitas Prima Indonesia, Sumatera Utara \\ Email: marulisirait@gmail.com
}

\begin{abstract}
ABSTRAK
Kelapa sawit merupakan komoditas unggulan di Kecamatan Kualuh Selatan Kabupaten Labuhanbatu Utara. Berdasarkan latar belakang, maka tujuan penelitian ini adalah menganalisis marjin dan farmer share atau kinerja indusri kelapa sawit. Pemilihan Kecamatan Kualuh Selatan sebagai lokasi penelitian dilakukan secara purposive (sengaja)dengan pertimbangan bahwa daerah tersebut sebagai daerah sentra produksi kelapa sawit.Lembaga yang terlibat dalam pemasaran komoditas kelapa sawit di Kecamatan Kualuh Selatan adalah agen kecil, agen besar dan pabrik. Masing-masing lembaga tersebut menjalankan fungsi pemasaran yang terdiri dari tiga fungsi pokok yaitu pertukaran, fisik dan fasilitas. Pola saluran pemasaran yang terbentuk untuk komoditas kelapa sawit ada tiga yaitu: 1) petani-pabrik; 2) petani-agen besar-pabrik 3) petaniagen kecil-agen besar-pabrik. Kinerja pasar kelapa sawit di Kecamatan Kualuh Selatan menunjukkan bahwah 3 saluran pemasaran dengan total marjin yang berbeda beda, semakin banyak lembaga pemasaran yang terlibat maka marjin pemasaran semakin tinggi, hal ini farmer share semakin rendah. Saluran yang paling efisien adalah saluran pemasaran 1 (petani-pabrik).
\end{abstract}

Kata Kunci : Pemasaran, Marjin, Farmer Share, Efisiensi.

\section{PENDAHULUAN}

Kelapa sawit memegang
peranan penting dalam sektor
perkebunan dan perekonomian
nasional yang dapat dilihat dari nilai Produk Domestik Bruto (PDB). Kelapa sawit memiliki beberapa Bahan produk turunan, yaitu: 1) Minyak Goreng, 2) Kosmetik, 3) Biodisel, dan lain sebagainya pasokan perkebunan kelapa sawit diarahkan untuk memenuhi kebutuhan konsumen dalam negeri, pasar tradisional, pasar modern, serta ekspor. komoditas kelapa sawit harus tersedia setiap saat dalam jumlah yang cukup, mutu baik, aman konsumsi, harga terjangkau, dan mampu diakses oleh seluruh lapisan masyarakat (Ditjen perkebunan, 2014).

Kelapa sawit merupakan komoditi utama perkebunan di Indonesia. Komoditas kelapa sawit mempunyai peran yang cukup strategis dalam perekonomian Indonesia. Pertama, minyak sawit merupakan bahan utama minyak goreng, sehingga pasokan yang kontinyu ikut menjaga kestabilan harga minyak goreng. Ini penting, sebab 
minyak goreng merupakan salah satu dari sembilan bahan pokok kebutuhan masyarakat sehingga harganya harus terjangkau oleh seluruh lapisan masyarakat. Kedua, sebagai salah satu komoditas pertanian andalan ekspor non migas, komoditas ini memiliki prospek yang baik sebagai sumber perolehan devisa maupun pajak. Ketiga, dalam proses produksi maupun pengolahan juga mampu menciptakan kesempatan kerja dan sekaligus meningkatkan kesejahteraan masyarakat (Soetrisno, 2008).

Indonesia merupakan negara produsen tanaman kelapa sawit yang

\section{METODE PENELITIAN}

Penelitian dilakukan di sentra perkebunan kelapa sawit di Kabupaten Labuhanbatu Utara, yaitu Kecamatan Kualuh Selatan sebagai fokus penelitian. Lokasi dipilih secara purposive (sengaja). Penelitian dilakukan pada April - Mei 2017.

Tabel 2. Jumlah Responden terdapat di 32 provinsi. Luas areal Tanaman kelapa sawit di Indonesia sebesar 11,67 juta $\mathrm{Ha}$, dengan jumlah produksi dilndonesia sebesar 33.50 juta Ton. Propinsi terbesar memproduksi kelapa sawit terdapat di Sumatera Utara dan Riau, rata-rata produksi sebesar 6,99 juta ton. Pada periode 2012-2016. (BPS 2012-2016).

Fluktuasi harga produk pertanian menjadi permasalahan utama dalam system pemasaran. Petani sering mengalami kerugian akibat fluktuasi harga.

\section{Metode Pengambilan Responden}

Jumlah populasi petani di Kecamatan Kualuh Selatan sebanyak 1.830, sampel diambil secara slovin, $\alpha=10 \%$. Data dan informasi yang didapat diolah dengan menggunakan Microsoft Excel 2010. Adapun jumlah responden dalam penelitian ini sebagai berikut:

\begin{tabular}{ll}
\hline Responden & Jumlah \\
\hline Petani diKecamatan Kualuh Selatan & 100 \\
pengumpul di kampung & 5 \\
Pengumpul di kecamatan(Bandar) & 3 \\
Total & 108 \\
\hline
\end{tabular}

\section{Analisis Perilaku Pasar}

Perilaku pasar merupakan aktivitas-aktivitas yang terjadi di pasar. Perilaku pasar berkaitan erat dengan struktur pasar dan kinerja pasar. Dengan adanya struktur pasar dan perilaku pasar akan membentuk kinerja pasar. Kohls dan Downey (1972) menjelaskan 3 fungsi pemasaran dalam perilaku pasar, yaitu fungsi pertukaran, fisik dan fasilitas (penyediaan sarana).

\section{Fungsi Pertukaran}

Fungsi pertukaran adalah kegiatan yang menyangkut pengalihan hak kepemilikan barang dari satu pihak ke pihak lain. Dalam fungsi pertukaran terdiri dari penjualan dan pembelian.

\section{Fungsi Fisik}

Fungsi fisik adalah kegiatan yang melibatkan penanganan, gerakan, dan perubahan fisik produk. Terdapat 3 fungsi di dalam fungsi fisik, yaitu pengangkutan, penyimpanan, dan pemrosesan. 
Agriprimatech

Vol. 3 No. 2, April 2020

\section{Fungsi Fasilitas}

Fungsi fasilitas atau penyediaan sarana adalah kegiatan yang memper-lancar fungsi pertukaran dan fisik dalam pemasaran, meliputi sortasi dan grading, informasi harga, penanganan risiko, dan pembiayaan.

Analisis Saluran Pemasaran merupakan perangkat organisasi yang saling bergantung satu sama lainnya, baik dalam menyediakan produk atau jasa yang digunakan oleh konsumen. Lembaga pemasaran bertujuan untuk memasarkan produk serta menyesuaikan permintaan dan penawaran. Saluran pemasaran yang efisien dapat mengurangi kesenjangan atau risiko yang akan terjadi, seperti risiko keterlambatan pengiriman maupun kesalahan tempat kepemilikan dikatakan bahwa sistem pemasaran tersebut efisien.

\section{Analisis Kinerja Pasar}

Salah satu indiktor yang dapat menunjukkan kinerja pasar adalah keuntungan yang diperoleh dalam suatu industri. Analisis kinerja pasar dapat dilihat dengan menghitung marjin pemasaran dan farmer share. Panjangnya saluran pemasaran yang ada belum tentu menunjukkan bahwa kinerja pemasaran tersebut tidak efisien. Jika rantai pema-saran panjang dan mampu meningkatkan kepuasan konsumen maka dapat dikatakan bahwa sistem pemasaran tersebut efisien.

\section{Marjin Pemasaran}

Asmarantaka (2012) menjelaskan definisi marjin sebagai cerminan dari aktivitas-aktivitas bisnis atau fungsifungsi pemasaran yang dilakukan dalam sistem pemasaran. Selain itu marjin adalah kumpulan balas jasa karena kegiatan

produktif (menambah atau menciptakan nilai guna) dalam mengalir-nya produk- produk agribisnis

$$
\text { e-ISSN :2621-6566 }
$$

mulai dari petani sampai ke tangan konsumen akhir.

Marjin dapat menunjukkan nilai tambah dari petani hingga sampai di tangan konsumen. Analisis marjin ini dapat digunakan untuk menganalisis sistem pemasaran dari perspektif makro (pemasaran produk dari petani hingga konsumen). Adapun rumus dari marjin pemasaran dapat dilihat sebagai berikut:

$\begin{array}{ll}\text { MT } & \text { Pr }\end{array}$

\section{Keterangan :}

MT = Marjin Total

$\operatorname{Pr} \quad=$ Harga Kelapa sawit di tingkat konsumen akhir(Rp/kg) Pf = Harga Kelapa sawit di tingkat petani $(\mathrm{Rp} / \mathrm{kg})$

\section{Farmer share}

Farmer share merupakan persentase harga yang diterima oleh petani dengan harga yang dibayarkan konsumen. Beberapa hal yang mempengaruhi farmer share, di antaranya tingkat pemrosesan, biaya transportasi, jumlah produk, dan keawetan produk. Farmer share berhu-bungan negatif dengan marjin pemasaran. Bila marjin pemasaran semakin tinggi, maka bagian yang diterima oleh petani semakin rendah. Farmer share dapat dihitung dengan rumus:

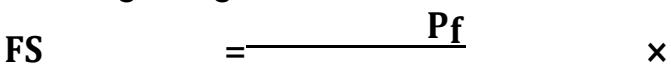

100persen

(3.8)

$\operatorname{Pr}$

\section{Keterangan :}

FS $=\quad$ Persentase yang diterima Petani

$\mathrm{Pr}=$ Harga kelapa sawit di tingkat konsumen $(\mathrm{Rp} / \mathrm{kg}) \mathrm{Pf}=$ Harga kelapa sawit di tingkat petani $(\mathrm{Rp} / \mathrm{kg})$ 


\section{Efisiensi Tataniaga}

Efisiensi suatu sistem tataniaga
diukur dari kepuasan konsumen,
produsen maupun lembaga-lembaga
yang terlibat dalam mengalirkan suatu
produk dari produsen primer (petani)
hingga sampai ke tangan konsumen.
Terdapat perbedaan pengertian
efisiensi tataniaga di mata konsumen
dan produsen. mengganggap suatu sistem tataniaga yang efisien adalah jika penjualan produknya mampu mendatangkan keuntungan yang tinggi bagi si produsen, sementara di mata konsumen suatu sistem tataniaga dinilai efisien jika konsumen bisa mendapatkan suatu produk dengan harga yang rendah.

Dalam menentukan tingkat kepuasan dari para lembaga/pelaku tataniaga sangatlah sulit dan sifatnya relatif. Efisiensi merupakan rasio dari nilai output dengan input. Menurut Purcell (1979); Kohls and Uhl (2002) dalam Asmarantaka (2009) indikator dalam mengukur efisiensi tataniaga produk agribisnis dapat dikelompokkan ke dalam dua jenis yaitu :

Efisiensi operasional atau teknis berhubungan dengan pelaksanaan aktivitas tataniaga yang dapat meningkatkan atau memaksimumkan rasio outputinput tataniaga. Efisiensi operasional adalah ukuran frekuensi dari produktivitas penggunaan inputinput tataniaga. Peningkatan efisiensi atau keuntungan dapat dilakukan melalui tiga kondisi (Halcrow, 1981; Seitz, Nelson and Halcrow, 1994 dalam Asmarantaka 2009) yaitu : menurunkan biaya tanpa menurunkan kepuasan konsumen, meningkatkan kepuasan konsumen tanpa meningkatkan biaya, meningkatkan kepuasan konsumen dengan peningkatan biaya dimana tambahan nilai output lebih besar dari tambahan nilai input. Keluaran per jam kerja merupakan salah satu rasio produktivitas yang biasanya digunakan sebagai tolak ukur efisiensi operasional (Downey dan Erickson 1992).

$$
\text { e-ISSN : 2621-6566 }
$$

Efisiensi Harga menekankan kemampuan sistem tataniaga dalam mengalokasikan sumberdaya dan mengkoordinasikan seluruh produksi pertanian dan proses tataniaga sehingga efisien sesuai dengan keinginan konsumen. Efisiensi harga bertujuan untuk mencapai efisiensi alokasi

\section{HASIL DAN PEMBAHASAN}

\section{Analisis Saluran Pemasaran}

Analisis sistem pemasaran kelapa sawit di Kecamatan Kualuh Selatan dari kebun petani hingga ke pabrik pengolahan melibatkan lembaga pemasaran. Lembaga pemasaran yang terlibat adalah agen kecil dan agen besar. Pada penelitian ini, budidaya kelapa sawit yang dijadikan lokasi penelitian berada di Kecamatan Kualuh Selatan yang termasuk di dalam wilayah Kabupaten Labuhanbatu Utara, Provinsi Sumatera Utara. Hasil produksi kebun kelapa sawit petani responden berupa tandan buah segar (TBS), yang selanjutnya diangkut ke lokasi pabrik pengolahan kelapa sawit (PKS) di sekitar wilayah Kabupaten Labuhanbatu utara, yaitu PKS PT KISS

Hasil penelitian terhadap 100 orang petani responden, dapat diketahui bahwa pola saluran pemasaran TBS melalui 3 pola saluran. Pola saluran I TBS petani dijual langsung ke PKS. Pada pola saluran II, TBS petani dijual kepada agen besar,kemudian langsung diangkut ke PKS. Pada pola saluran III, TBS petani dijual kepada agen kecil, kemudian melalui agen besar diangkut ke PKS.

\section{Saluran Pemasaran I.}

Terdapat 8 orang petani sampel. Petani yang tidak begitu luas kebun kelapa sawit mempunyai saluran pemasaran yang sangat sederhana. di Kecamatan Kualuh Selatan. Pada saluran I ini petani langsung menjual tandan buah segar (TBS) ke pabrik 
Agriprimatech

Vol. 3 No. 2, April 2020

kelapa sawit. Jumlah rata-rata yang dijual selama satu tahun adalah 2.211.303 $\mathrm{Kg} / \mathrm{Tahun}$ dengan rata-rata harga Rp.1.401 per kg. Pada umumnya pada saluran I haga jual bagi petani adalah yang paling tinggi dan share margin yang paling tinggi. Bagi petani kelapa sawit lain juga sebernarnya berkeinginan melakukan penjualan tanda buah segar (TBS) langsung ke pabrik seerti saluran pemasaran I ini. Tapi karena volumenya (penjualan) tanda buah segar (TBS) cukup kecil maka tidak dilakukan petani.

\section{Saluran Pemasaran II : Petani-Agen Besar-Pabrik}

Rata-rata jumlah kelapa sawit yang dipasar kan selama setahun yaitu sebesar2.662.641 Kg/Tahun dengan rata-rat yang diterima petani sebesar Rp.1.172 per kg. Dan rata-rata harga penjualan kelapa sawit yang agen besar yaitu sebanyak Rp.1.403 per kg. Kelapa sawit dipasarkan oleh 3 agen besar.

\section{Saluran III: Petani - Agen Kecil - Agen Besar - Pabrik}

Pada saluran III petani menjual tanda buah segar (TBS) ke agen kecil sebanyak $3.837 .429 \mathrm{~kg}$,rata-rata harga yang diterima petani yaitu Rp.1.115 per kg. Agen kecil ini langsung memasarkan ke agen besar. Harga yang diterima oleh agen besar yaitu $R p$ 1.172per kg. Pada saluran III ini.

Berdasarkan skema yang terlihat pada Gambar 1-3, terbentuk suatu sistem pemasaran yang merupakan kesatuan yang saling berkaitan satu sama lain antar lembaga pemasaran. Pada saluran diatas maka hipotesis 2 dalam

$$
\text { e-ISSN :2621-6566 }
$$

penelitian ini yang menyatakan bahwa daerah penelitian terdapat beberapa macam atau jenis saluran pemasaran kelapa sawit dapat diterima.

\section{Analisis Kinerja Pasar}

Penentuan tingkat efisiensi
suatu sistem pemasaran dapat
dilakukan melalui pendekatan análisis
marjin pemasaran. Marjin pemasaran
adalah penjumlahan dari seluruh biaya
pemasaran yang dikeluarkan oleh
lembaga pemasaran dan besarnya
keuntungan yang diambil dalam
aktivitas penyaluran komoditas dari
lembaga pemasaran yang satu ke
lembaga pemasaran lainnya. Marjin
pemasaran yang diperhitungkan dalam
penelitian ini berdasarkan pada pola
saluran pemasaran yang terbentuk
dalam aktivitas pemasaran TBS kelapa
sawit di Kecamatan Kualuh selatan.
Dalam penelitian ini, marjin pemasaran
dapat dilihat disetiap saluran
pemasaran.

\section{Marjin Pemasaran}

Marjin pemasaran adalah selisih antara harga yang diterima petani dengan harga yang dibayar oleh agen. Marjin untuk setiap saluran pemasran tandan buah segar (TBS) dapat dilihat pada Tabel 15,16,17 dan 18. Pada saluran pemasaran I petani langsung menjual tanda buah segar (TBS) ke pabrik, artinya tidak melalui lembaga perantara dalam memasarkan hasilnya. Oleh karena itu, harga yang diterima petani sebesar Rp. 1.403, total biaya sebesar Rp. 433,- dengan marjin 31,61 persen, keuntungan petani dalam saluran pemasaran I sebesar Rp. 961 dengan marjin 68,39 persen.

Tabel 10. Marjin Pemasaran Pada Saluran I

\begin{tabular}{lll}
\hline Uraian & Price Spread & Share Margin \\
& $\mathrm{Rp} / \mathrm{Kg}$ & $\%$ \\
\hline
\end{tabular}

Harga Jual produsen 
Agriprimatech

Vol. 3 No. 2, April 2020

e-ISSN : 2621-6566

Total Biaya

433

31,61

Keuntungan petani

961

68,39

Jumlah

2.797

100

Marjin

0

Sumber:Analisis data Primer lampiran 7. Rata-rata harga kelapa sawit tahun 2016

Pada saluran pemasaran II petani langsung menjual ke agen besar, dan rata- rata harga yang diterima petani sebesar Rp. 1.172 per kg, dan rata-rata total biaya yang di keluarkan petani sebanyak Rp. 351 per kg, dengan marjin 29,95 persen, dengan keuntungan petani sebesar Rp. 821 per $\mathrm{kg}$ dengan marjin sebesar 70,05 persen. Dan pembelian tanda buah segar oleh agen besar adalah $\mathrm{Rp}$. 1.172 per $\mathrm{kg}$ dengan marjin 83,53 persen, dan rata-rata biaya sebesar Rp.249 per kg dengan marjin 9,19 persen dan pendapatan agen besar sebanyak Rp. 102 per kg dengan marjin 7,27 persen. Pada saluran II ini marjin sebanyak Rp. 231 dengan marjin 16,46 .

Tabel 11. Marjin pemasaran pada saluran II

\begin{tabular}{lll}
\hline Uraian & $\begin{array}{l}\text { Price Spread } \\
\mathrm{Rp} / \mathrm{Kg}\end{array}$ & $\begin{array}{l}\text { Share Margin } \\
\%\end{array}$ \\
\hline Harga Jual petani & 1.172 & \\
Total Biaya & 351 & 29,95 \\
Keuntungan petani & 821 & 70,95 \\
Jumlah & & 100 \\
Harga Agen 1 & 1.172 & 83,53 \\
Total Biaya & 249 & 9,19
\end{tabular}


Marjin Pada Saluran Pemasaran III dapat dilihat pada Tabel 17. Dapat diketahui bahwa harga jual petani adalah Rp.1.115 per kg. Rata-rata Biaya yang dikeluarkan petani sebesar Rp.569 dengan marjin 29,95 persen. Pendapatan petani sebesar Rp.636 per $\mathrm{kg}$ dengan marjin adalah 83 persen. Harga beli agen kecil adalah sebesar
Rp. 1.115 dengan marjin 83,59 persen dan biaya keseluruhan sebesar Rp.193 per $\mathrm{kg}$ dengan marjin 9,19 persen. Dan pendapatan sebesar Rp. 190 per kg dengan marjin 86 persen. Selisih harga pada saluran pemasaran III ini yaitu $R p$. 478 dengan total marjin sebesar 37 persen

Tabel. 12. Marjin Pemasaran Pada Saluran III

\begin{tabular}{|c|c|c|}
\hline Uraian & Price Spread & Share Margin \\
\hline & $\mathrm{Rp} / \mathrm{Kg}$ & $\%$ \\
\hline Harga Jual petani & Rp. 1.115 & \\
\hline Total Biaya & Rp. 569 & \\
\hline Keuntungan petani & Rp. 636 & $83 \%$ \\
\hline Jumlah & & $83 \%$ \\
\hline Harga Beli & Rp 1.115 & \\
\hline Total Biaya & Rp. 193 & \\
\hline Pendapatan Agen Kecil & Rp.190 & $86 \%$ \\
\hline Harga Jual Agen Kecil & Rp. 1.115 & \\
\hline Jumlah & & 86 \\
\hline Harga yang diterima agen besar & Rp. 1.300 & \\
\hline Marjin Agen kecil-petani & Rp. 247 & 21,07 \\
\hline Marjin Agen Besar-agen kecil & Rp. 185 & 16,46 \\
\hline Total Marjin & Rp. 478 & $37 \%$ \\
\hline
\end{tabular}

Sumber:analisis data primer lampiran 9.Rata-rata harga kelapa sawit tahun 2016

\section{Farmer Share}

Farmer's share adalah perbandingan tingkat harga yang diterima oleh petani dengan harga yang dibayarkan oleh konsumen akhir. Farmer's share merupakan konsep balas jasa atas kegiatan usahatani. Berdasarkan hasil penelitian, besarnya farmer's share petani kelapa sawit di Kecamatan Kualuh Selatan berbeda untuk masing-masing saluran pemasaran. Semakin tinggi farmer's share maka semakin rendah marjin pemasaran, Sinaga (2014).

Tabel 13 menunjukkan farmer's share tertinggi terdapat pada saluran Tabel 13. Analisis Farmer'sShare pemasaran I (petani - pabrik) yaitu sebesar 100 persen dengan harga jual ditingkat petani dan pabrik sama yaitu Rp. 1.403,- sedangkan farmer's share terendah terdapat pada saluran III (petani - Agen kecil - agen besar pabrik) yaitu sebesar 65,94 persen. Perbedaan farmer share yang terjadi pada setiap saluran pemasaran dikarenakan adanya perbedaan harga yang diterima setiap lembaga pemasaran, jumlah lembaga pemasaran yang terlibat serta fungsifungsi yang dilakukan sehinggah meningkatkan harga di tingkat konsumen. Rahmawati (2013).
Saluran

pemasaran
Harga di tingkat Harga di tingkat petani $(\mathrm{Rp} / \mathrm{kg}) \quad$ Konsumen $(\mathrm{Rp} / \mathrm{kg})$
Farmers share

(\%) 
Agriprimatech

\begin{tabular}{lrlll} 
Vol. 3 No. 2, April 2020 & \multicolumn{2}{c}{ e-ISSN :2621-6566 } \\
I & 1.403 & 1.403 & 100 & \\
II & 1.172 & 1.403 & 83,53 \\
III & 1,115 & 1.403 & 65,94
\end{tabular}

Sumber: Analisis Data Primer

\section{Efisiensi Tataniaga}

Efisiensi merupakan salah satu tujuan yang hendak dicapai dalam suatu aktivitas tataniaga. Sistem tataniaga dapat dikatakan terlaksana secara efisien apabila kepuasan dari setiap pihak atau lembaga yang terlibat dalam pelaksanaan sistem tataniaga dapat tercapai. Pihak atau lembaga tidak hanya terdiri dari para pelaku yang terlibat dalam proses penyaluran produk, melainkan hingga tingkat konsumen akhir. Hal yang dapat dijadikan sebagai indicator penentu efisiensi dari Suatu aktivitas tataniaga diantaranya pola saluran tataniaga yang terbentuk,

penerapan fungsi tataniaga dalam penyaluran produk, struktur pasar, perilaku pasar dan nilai marjin tataniaga serta farmer's share yang terbentuk. Pada penentuan efisiensi tataniaga kelapa sawit di Kecamatan Kualuh Selatan dilakukan penyetaraan standarisasi kualitas tandan buah segar pada setiap saluran tataniaga untuk membandingkan nilai efisiensi masingmasing saluran. Komponen-komponen yang diperhitungkan dalam menentukan nilai efisiensi tataniaga.

Tabel 14.Efisiensi Tataniaga

\begin{tabular}{|l|l|l|l|l|}
\hline $\begin{array}{l}\text { Saluran } \\
\text { pemasaran }\end{array}$ & $\begin{array}{l}\text { Harga di } \\
\text { tingkat } \\
\text { petani (Rp/kg) }\end{array}$ & $\begin{array}{l}\text { Harga di Pabrik } \\
(\mathrm{Rp} / \mathrm{kg})\end{array}$ & Marjin (\%) & $\begin{array}{l}\text { Farmers share } \\
(\%)\end{array}$ \\
\hline$I$ & 1.403 & 1.403 & 0 & 100 \\
\hline II & 1.172 & 1.403 & 16,64 & 83,53 \\
\hline III & 1,115 & 1.403 & 37 & 65,94 \\
\hline
\end{tabular}

Tabel 14 menyajikan data mengenai nilai efisiensi tataniaga pada setiap pola saluran tataniaga yang terbentuk dengan kondisi produk kelapa sawit dengan kualitas yang relatif sama. Berdasarkan data tersebut dapat dilihat dari nilai marjin dan farmer's share maka saluran I lebih efisien dibandingkan saluran II dan III, dengan nilai marjin sebesar 0 persen dan farmer's share 100, karena lembaga pemasaran satu tidak mengunakan lembaga pemesaran ( agen ), harga yang direrima petani sama dengan harga yang ada di PKS.

\section{KESIMPULAN}

1.Proses tataniaga kelapa sawit di Kecamatan Kualuh Selatan yang dimulai dari petani sebagai penghasil (produsen) hingga pabrik pengolahan, melibatkan beberapa lembaga pemasaran. Lembaga yang terlibat dalam tataniaga kelapa sawit di lokasi penelitian adalah pedagang pengumpul dan agen perantara. Saluran yang paling banyak digunakan oleh petani responden dalam memasarkan kelapa sawitnya adalah saluran pemasaran

2. Perilaku pasar pada industri kelapa sawit di Kecamatan Kualuh Selatan dapat dilihat dari strategi harga dan strategi produk. Strategi harga dilakukan dengan kolusi antar pelaku pasar yaitu menjadikan biaya produksi tertinggi sebagai pertimbangan harga penjualan. Kecamatan Kualuh Selatan menunjukkan terdapat beberapa lembaga pemasaran yaitu petani, agen kecil, agen besar, pabrik. Masing-masing lembaga pemasaran melakukan fungsi-fungsi pemasaran. 
Agriprimatech

Vol. 3 No. 2, April 2020

Pada aktivitas pemasaran adanya ikatan permodalan yang dilakukan petani dengan agen kecil maupun agen besar menyebabkan ikatan kontrak. Di Kecamatan Kualuh Selatan mempunyai 3 saluran pemasaran.

\section{DAFTAR PUSTAKA}

Asmarantaka RW. 2012. Pemasaran Agribisnis (Agri marketing). Departemen Agribisnis, Fakultas Ekonomi dan Manajemen. Institut Pertanian Bogor.

[BPS] Badan Pusat Statistik. 2015. Statistik Kelapa Sawit Indonesia. Medan. [BPS] Badan Pusat Statistik. 2015. Statistik Kelapa Sawit Indonesia. Medan.

BPS Badan Pusat Statistik. 2014. Luas Tanaman dan Produksi Kelapa Sawit Tanaman Perkebunan Rakyat. Medan.

BPS Badan Pusat Statistik. 2014. Luas Tanaman dan Produksi Kelapa Sawit Tanaman Perkebunan Rakyat. Medan.

Buana L, Siahaan D, Adiputra S. 2007. Teknologi Pengolahan Kelapa Sawit dan Produk Turunannya. Medan (ID): Pusat Penelitian Kelapa Sawit.

Direktoral jendral perkebunan. 2015. Luas Areal Kelapa Sawit Indonesia. Jakarta. Direktorat Jendral Perkebunan. 2014. Produk Domesik Bruto. Pusat Data dan

Informasi.Jakarta.

Dahl DC, Hammond JW. 1977. Market and Price Analysis. Mc. Graw Hill, New York.

Fauzi Y, Widyastuti EY, Satyawibawa I, Hartono R. 2002. Kelapa sawit, Budidaya Pemanfaatan Hasil dan Limbah Analisis Usaha dan Pemasaran. Depok (ID): Penebar Swadaya.

$$
\text { e-ISSN :2621-6566 }
$$

Hirschey M. 2009. Managerial Economics: An Integrative Approach. New Delhi (IN). Cengage Learning.

Higgins et al. 2007. Harga Kelapa Sawit Tingkat Konsumen dan Produsen.

Yogyakarta.

Jaya, W.K. 2001. Ekonomi Industri. BPFE, Yogyakarta.

Kohls RL, Uhl JN. 2002. Marketing of Agricultural Products. Prentice Hall. New Jersey

Kohls RL, Downey WD. 1972. Marketing of Agricultural Products 4th edition.

Macmillan Publishing. New York.

Lestari. 2006. Analisis Efisensi Penggunaan factor-Faktor Produksi dan Pendapatan Petani Kelapa sawit lahan kering [skripsi]. Bogor: Fakultas Ekonomi dan Manajemen, Institut Pertanian Bogor

Lubis. SN. 2006. Teori Pasar I : Pasar Monopoli. Fakultas Pertanian USU. Medan

Natalia, A.J. 2016. Analisis Kelayakan Finansial Usahatani Kopi Arabika (Coffea arabica). Program Studi Agribisnis Fakultas Pertanian Universitas Sumatera Utara. Medan.

Maimun. 2009. Analisis Pendapatan Usaha Tani, Nilai Tambah, dan Saluran Pemasaran Kopi Arabika Organik dan Non Organik Aceh Tengah [skripsi]. Bogor: Fakultas Pertanian, Institut Pertanian Bogor

Sinaga et al. 2014. Fluktuasi Harga pada Produk Pertanian. Yogyakarta. Soetrisno. 2008. Nilai peran strategis dalam 
Agriprimatech

Vol. 3 No. 2, April 2020

$e-I S S N \quad: 2621-6566$

perekonomian Indonesia.

Yenni. 2005. Optimalisasi Pengadaaan

Kelapa Sawit Sebagai Bahan

Baku [skripsi].

Bogor: Fakultas Pertanian, Institut Pertanian Bogor 